\title{
Hydrochemical Characteristics of Water Quality Around Nkalagu Area, Southern Benue Trough, Nigeria Using Multivariate Statistical Analysis
}

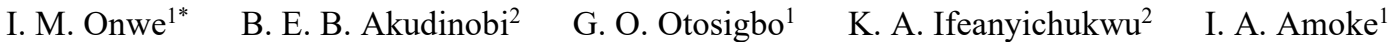 \\ 1.Department of Physics/Geology/Geophysics, Alex Ekwueme Federal University Ndufu-Alike, Nigeria \\ 2.Department of Geological Sciences, Nnamdi Azikiwe University, Awka, Nigeria
}

\begin{abstract}
Hydrochemical characteristics of water quality around Nkalagu area has been studied and characterized using multivariate statistical analysis. Eighty water samples were collected in the area from spatially referenced boreholes, hand dug wells abandoned mines, catch pits and rivers located in and around the Nkalagu area and were analyzed for EC, $\mathrm{pH}$, TDS, TH, $\mathrm{Ca}^{2+}, \mathrm{Mg}^{2+}, \mathrm{Na}^{+}, \mathrm{K}^{+}, \mathrm{HCO}_{3}^{-}, \mathrm{Cl}^{-}, \mathrm{NO}_{3}{ }^{-}, \mathrm{SO}_{4}{ }^{2-}$ and $\mathrm{Fe}^{2+}$ according to EPA and APHA standards. Based on mean values, the order of abundance in ions is $\mathrm{Cl}^{-}>\mathrm{HCO}_{3}{ }^{-}>\mathrm{SO}_{4}{ }^{2-}>\mathrm{NO}_{3}{ }^{-}$, for anions and $\mathrm{Na}^{+}>\mathrm{Ca}^{2+}>\mathrm{Mg}^{2-}>\mathrm{K}^{+}$, for cations. TDS and Salinity hazard classifications characterized the water in the study area as soft to very hard with low to very high salinity hazard. Principal component analysis (PCA) reduced the hydrochemical data into two principal components which explain $78.553 \%$, of the total variance that characterize the water quality in relation to the source of its hydrochemistry. Cluster analysis (CA) grouped eighty water samples in the area into eight clusters of similar water quality characteristics related to water-rock interaction, agriculture and anthropogenic sources. Discriminant analysis (DA) showed that the discriminating parameters of water quality in the area are $\mathrm{EC}$, TDS, $\mathrm{TH}, \mathrm{SO}_{4}, \mathrm{Cl}, \mathrm{Mg}, \mathrm{Ca}, \mathrm{Na}$, and $\mathrm{HCO}_{3}$ and this revealed that water quality in the area is controlled by both geogenic and anthropogenic processes.
\end{abstract}

Keywords: Water Quality, Multivariate analysis, cluster analysis, principal component analysis

DOI: $10.7176 / \mathrm{JEES} / 9-11-07$

Publication date: November $30^{\text {th }} 2019$

\section{Introduction}

Nkalagu area falls within the Southern Benue Trough and well knows for limestone mining and agricultural activities, mainly crop production. Mining activities in the area has been carried out using open-cast method over three decades now (Ezekwe et al. 2012) and this method has great potential to impact negatively on the available water resources. Mine water from the open-cast pit and solid waste generated are discharged in the stream and the river indiscriminately across the area without any treatment. And this water constitutes the main sources of water supply for drinking, domestic and agricultural purposes in the area which are grossly inadequate for the inhabitants with unreliable quality and inhabitants consume same ignorantly. The quality of water determines its potability and usefulness for various purposes.

The area is fast increasing in population and infrastructural development due to the presence of new companies in the area in addition to NIGERCEM, thereby, increasing water demand. To meet the demand for water in the area, individual households have resorted to the use of shallow hand dug wells and boreholes that tap the unconfined weathered/fractured Nkalagu formation. Unfortunately, most of these household hand dug wells and boreholes are poorly sited, as they are close to drainage systems, refuse dumps and cesspools. The prevailing geologic, hydrogeologic and sanitation conditions in the area increases the potentials for qualitative devaluation of the available water resources.

An understanding of the hydrochemical characteristics of water resource in the area will give insight into the underlying factors/sources controlling the quality of water, flow regime and water management practices. Environmental factors that determine the quality of water supply source are related either to geogenic processes or to anthropogenic activities (Omonona et al. 2019).

Multivariate analysis is the area of statistics that are widely used for analyzing large water quality and dataset with minimal loss of important information (Samson \& Elangovan 2007). This statistical technique which expresses principal component analysis (PCA), cluster analysis (CA), and discriminant analysis (DA) has been employed by many researchers in the study of groundwater quality and characteristics (Ribeiro \& Macedo 1995; Shihab \& AbdulBaqi 2010; Lu et al. 2011; Mahmood et al. 2011; Okogbue et al. 2012, Omonona et al. 2014, Omonona \& Okagbue 2017; Omonona et al. 2019). They were able to identify the principal controlling processes of all sampled wells using multivariate statistics techniques.

Previously studies in the area include the notable works done by Fayose \& De Klasz (1976) and Eyankware et al. (2018). Fayose \& De Klasz (1976), worked on the age, biostratigraphy and environment of deposition of the formation and Eyankware et al. (2018), assessed the water quality in abandoned limestone quarry pit. Presently, no work has been done in the area on the hydrochemical characteristics of water quality since mining activities 
started. There is need to investigate the feasibility of water resources in the area as an alternative procedure for water demand purposely.

This study is aimed at assessing the present hydrochemical characteristics of water in the area using multivariate analysis so as to provide a guide to future planning and development of water in the area.

\section{Study Area Setting}

The study area is bounded within the latitudes $6^{0} 10^{\prime} \mathrm{N}$ and $6^{0} 40^{\prime} \mathrm{N}$ and longitudes $7^{0} 35^{\prime} \mathrm{E}$ and $7^{0} 50^{\prime} \mathrm{E}$ on the scale of 1:100,000 (Fig. 1) and is accessible through a network of major roads, minor roads and footpaths that link the communities. The area is drained by the Ebonyi River and its tributaries which are mostly perennial in nature generally flow in N-W direction into the Ebonyi River and exhibit dendritic drainage pattern.

Nkalagu area is within the Guinea Savannah vegetation belt characterized by scattered trees, shrubs and bushes. It has a moderate relief that ranges from 125 to $250 \mathrm{~m}$ above mean sea level (Inyang 1975). The major landforms are the undulating limestone outcrops, the valley ridges and the low lands. The climate is tropical and dominated by two distinct seasons: the rainy and dry seasons. The rainy season begins in April and ends in October and dry season begins in November and ends in March. The area experience annual mean rainfall of 1,750 $\mathrm{mm}$ and the mean daily temperature ranges from 22 to $32{ }^{\circ} \mathrm{C}$ (Onwuka et al. 2004; Omonona et al. 2014).

Nkalagu area is underlain by the Nkalagu Formation which consists of black shales, limestones and siltstone (Fig. 1). The black shales are fractured which constitutes the only known aquifer in the area, and because it is some places, intercepted by fresh bedrock, it is generally discontinuous. The aquifer is recharged by precipitation. An alternating sequence of thick limestone units occur with calcareous shales in many places within Nkalagu Formation (Ikhane et al. 2009). The limestone beds in the area trend mostly NE-SW, with dip direction in NW and dip amount ranging from $6^{0}$ to $8^{0}$; a total of twenty-five limestone beds have identified and serially numbered by Amajor (1992).

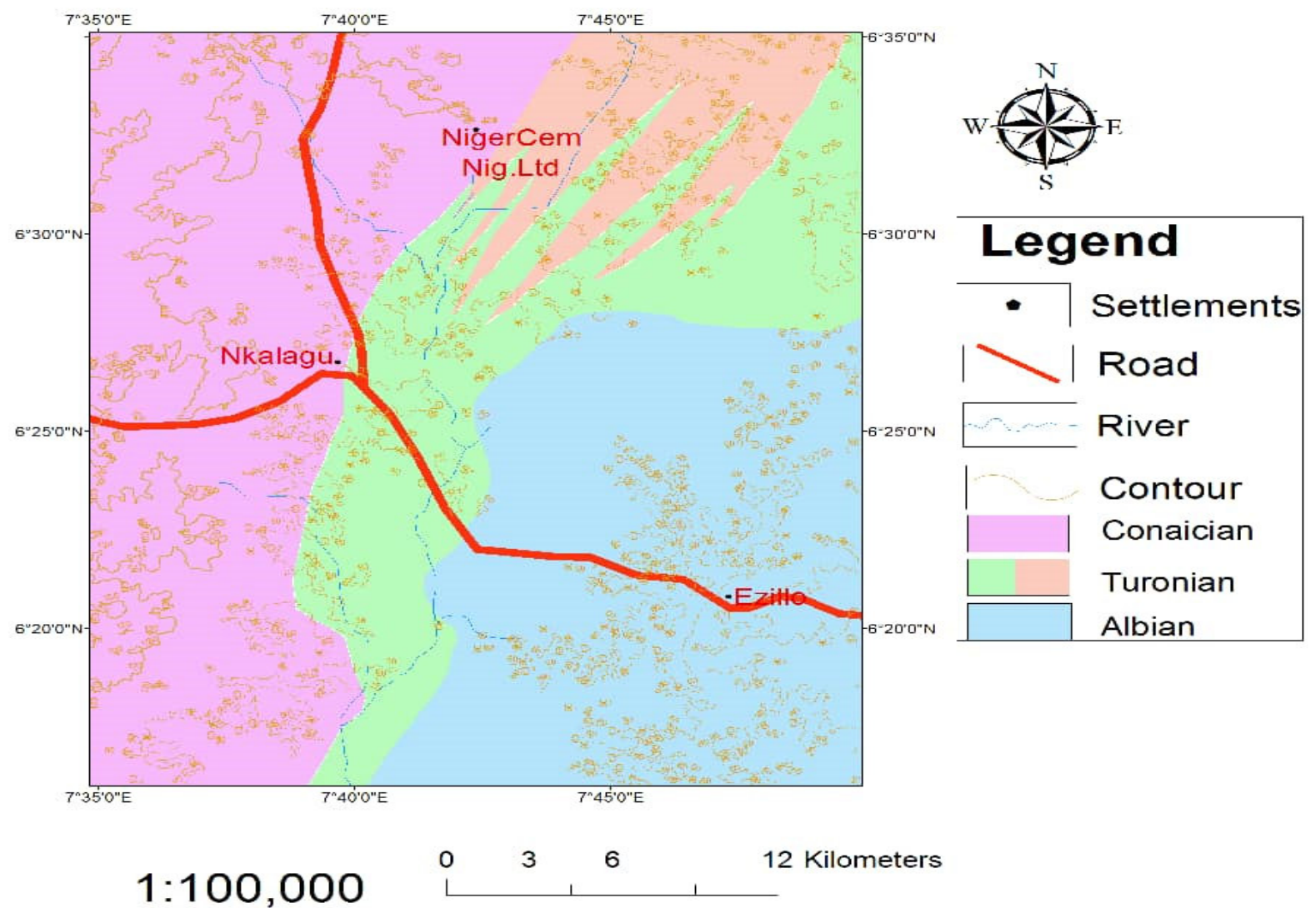

Figure 1 Geological map of Nkalagu area, Southeastern Nigeria

\section{Materials and methods}

The hydrochemical characteristics of the surface water and groundwater in the study area were determined through the field measurements of physiochemical parameters and laboratory analyses of anions and cations in samples collected from different sources in the area. Global Positioning System (GPS) was used to take latitude, longitude and elevation above sea level of location at each sample point.

A total of 80 water samples were collected from different sources ( 45 from borehole $(\mathrm{BH}), 15$ from hand dug 
wells (HDW), 13 from abandoned mine (AM), 3 from Catch pit (CP) and 4 from river (RV) in the month of March, 2019. The sampling locations were selected in order to cover residential, agricultural and industrial area so as to achieve a good sampling representation of the study area. Physiochemical parameters such as temperature (Temp), $\mathrm{pH}$, total dissolve solid (TDS) and electrical conductivity (EC) were measured immediately in the field at each point once the sample was collected with the aid of field probes due to their transient characteristics and the remaining parameters were determined in the laboratory within 24 hours. Two set of samples were collected at each point. One set for anions test while the remaining set is for cations and were stabilized with two to three drops of diluted $\mathrm{HCl}$. Samples were collected in pre-cleaned sterilized plastic bottles and stored in an ice box and the preservation and transportation of water samples were performed according to standard methods (APHA 2005). Chemical analyses were carried out at the chemical research laboratory, Abakaliki, Nigeria. The analytical methods used in the determination of the hydrochemical parameters are in accordance with the World Health Organization (WHO 2011) standards and in each of the samples, 14 parameters were tested for. Iron, Calcium, sodium, potassium and magnesium were determined by atomic absorption spectrophotometry. Chloride, nitrate and sulfate were determined by ion chromatography, bicarbonate and total hardness by Potentiometric titration. The accuracy of the chemical analysis was verified by calculating charge ratio between the sum of cations and sum of anions. Water samples result in the study area was classified and compared according to US Salinity Laboratory Staff (1954) based on EC, Davis \& DeWiest (1996) based on TDS, Freeze \& Cherry (1979) based on TDS and Sawyer \& McCarty (1967) based on TH.

Three multivariate analysis techniques, namely, principal component analysis (PCA), cluster analysis (CA) and discriminant analysis (DA) were employed in characterizing the water quality in the study area. All the statistical analyses were carried out using Stagraphics Centurion XVI. The data were first of all standardized before they were used as input data in order to correct the effects of the varied range of measurements of the various parameters and differences in the units of measurements (Singh et al. 2004; Singh et al. 2009; Mohapatra et al. 2011). PCA, CA and DA were based on 13 physicochemical parameters as input variables in eighty water samples. Principal components with Eigenvalues $\geq 1.0$ were considered significant (Kaiser 1958; Harman 1967). Principal component weight or factor loading $\geq 3.0$ were considered significant for the physicochemical parameters and principal scores loadings $\geq 1.0$ were considered significant on the water sampling location (Senthilkumar et al. 2008; Ayuba et al. 2013). Cluster analysis was based on Ward's method and squared Euclidean distance metric mode (Ward 1963; Güler et al. 2002). The discriminating factor used for the DA was the pollution loading class defined and identified by PCA and CA respectively. The data inputted were data collected in 80 different locations in the year 2019 after mining activities had resumed in the area.

\section{Results and Discussion}

\subsection{Hydrochemical Characteristics}

The result of the water analyses and the World Health Organization (WHO 2011) and Standard Organization of Nigeria (SON 2007) guideline limits is presented in Table 1. Table 1 shows the descriptive statistics (minimum, maximum, mean and standard deviation) overview of the chemistry of water in the study area generated from the analysis of the water samples collected in dry season. The range, mean and standard deviation values reveal considerable variations in the water samples with respect to their chemical composition. The $\mathrm{pH}$ values of water samples in the study area ranged from 5.25 to 8.25 (mean = 7.27). This reveals that the water in the study area is acidic to slightly alkaline in nature. EC is a measure of the total ionic components in water; the more solutes present in water, the higher the EC. The EC values in water samples ranged from 8.0 to $3996.0 \mu \mathrm{S} / \mathrm{cm}$ with a mean value of $1081.79 \mu \mathrm{S} / \mathrm{cm}$. However, high values of EC were recorded in groundwater samples in the study area. The groundwater samples show very high EC values, especially in the dry season. This high values in the groundwater samples can be attributed to the high content of charged ions due to oxidation processes going on in the area. EC values revealed the high diversity in the geochemical processes that shape the chemistry of water in the area. The TDS values in water samples ranged from 75.0 to $1879.0 \mathrm{mg} / \mathrm{l}$ with a mean value of $545.96 \mathrm{mg} / \mathrm{l}$. Presence of high level of TDS in water $(>1200 \mathrm{mg} / \mathrm{l})$ can cause objectionable to consumers WHO (2011). The mean of water samples in the area exceeded the criteria of SON (2007) and WHO (2011). It was observed that some water samples show very high TDS values $(>120 \mathrm{mg} / \mathrm{l})$. EC and TDS value was also observed to increase with depth in the groundwater samples. The high concentrations of TDS and EC in the groundwater samples might be attributed to the more pronounced water-rock interaction, such as the mineral dissolution and evaporation concentration functions of the host rock. These high TDS concentrations are due to the presence of high $\mathrm{HCO}_{3}{ }^{-}$, $\mathrm{SO}_{4}{ }^{2-}, \mathrm{Cl}^{-}, \mathrm{Ca}^{2+}$ and $\mathrm{Na}^{+}$as showed in Table 1. According to Jaine et al. (2003), water that contains such high concentration of TDS could cause gastrointestinal irritation. High values of TDS also influence the taste, hardness, and corrosive property of the water (Haran 2002; WHO 2011). The hardness of water limits its use for domestic and agricultural activities. The TH values in water samples ranged from 32.44 to $467.78 \mathrm{mg} / \mathrm{l}$ with a mean value of $189.98 \mathrm{mg} / \mathrm{l}$. Hardness in water in the study area is mostly due to the high TDS compared to $\mathrm{Ca}^{2+} \mathrm{and}^{\mathrm{Mg}^{2+}}$ concentrations. 
The calculated charge ratio between the sum of cations and sum of anions was $\pm 1.4 \%$, which is within the acceptable limits of $< \pm 5 \%$ which confirms the reliability of the analytical results (Datta \& Subramanian 1998; Singh \& Hassin 2002). $\mathrm{Na}^{+}$and $\mathrm{Ca}^{2+}$ dominate the observed cations concentration in water samples with mean values of $52.28 \mathrm{mg} / \mathrm{l}$ and $43.69 \mathrm{mg} / \mathrm{l}$ (Table 1) respectively. These ions represent $42.68 \%$ and $35.67 \%$ of the total major cations of water samples respectively while $\mathrm{Mg}^{2+}$ represents $16.05 \%$ and $\mathrm{K}^{+}$represents only $5.60 \%$ of the total major cations of water samples (Table 2). $\mathrm{Cl}^{-}$and $\mathrm{HCO}_{3}{ }^{-}$dominate the anions concentration with mean values of $103.01 \mathrm{mg} / \mathrm{l}$ and $100.42 \mathrm{mg} / \mathrm{l}$ respectively. These ions represent $34.59 \%$ and $33.72 \%$ of the total major anions respectively while $\mathrm{SO}_{4}{ }^{2-}$ represents $26.25 \%$ and $\mathrm{NO}_{3}{ }^{-}$represents only $16.21 \%$ of the total major anions of water samples.

The Fe values in dry season ranged from 0.01 to $5.52 \mathrm{ppm}$ with a mean value of $0.77 \mathrm{ppm}$. The abundance of the major ions in the water samples in descending order is $\mathrm{Cl}^{-}>\mathrm{HCO}_{3}{ }^{-}>\mathrm{SO}_{4}{ }^{2-}>\mathrm{NO}_{3}{ }^{-}$for anions and $\mathrm{Na}^{+}>\mathrm{Ca}^{2+}>$ $\mathrm{Mg}^{2-}>\mathrm{K}^{+}$for cations. The standard deviations of the hydrochemical variables in general indicate that the water in the study area is heterogeneous and reveals the influence of complex contamination sources and geochemical processes. This variation could be attributed to differences in salinity and ionic composition. According to the US Salinity Laboratory (1954) classification $9 \%$ of the water samples are classified as "Low class", $17 \%$ as "Medium class" $55 \%$ as "High class" and $19 \%$ as "Very high class" as shown in Table 3. Consumption of such water could lead to gastro intestinal irritation. According to Davis \& Dewiest (1966) water classification based on TDS (Table 4) classified $44 \%$ of the water samples as "Desirable water" $34 \%$ as "Permissible water" and $22 \%$ as "Useful irrigation". Freeze \& Cherry (1979) classification based on TDS (Table 5) also classified $78 \%$ of the water samples as "Fresh water" and $22 \%$ as "brackish water". Water classification based on TH value (Table 6) classified water in the study area as "Soft water type to very hard water type" according to Sawyer \& McCarty (1967) water classification and will definitely require softening prior to domestic use. Hardness in water can give rise to the formation of scum (whitish scale) in pots, boiler rings, and irrigation equipment; it may also cause health problems to humans such as kidney failure (WHO 2011).

Table 1 Water physical and chemical quality descriptive statistics with WHO (2011) and SON (2007) Limits

\begin{tabular}{|l|l|l|l|l|l|l|l|}
\hline Parameters & Season & Minimum & Maximum & Mean & $\begin{array}{l}\text { Std } \\
\text { deviation }\end{array}$ & $\begin{array}{l}\text { WHO } \\
(2011)\end{array}$ & $\begin{array}{l}\text { SON } \\
(2007)\end{array}$ \\
\hline Temp $\left({ }^{0} \mathrm{C}\right)$ & Dry & 28.00 & 32.50 & 30.54 & 0.93 & 31 & - \\
\hline $\mathrm{pH}$ & Dry & 5.25 & 8.25 & 7.07 & 1.32 & $6.5-8.5$ & - \\
\hline $\mathrm{EC}(\mu \mathrm{S} / \mathrm{cm})$ & Dry & 8.00 & 3996.00 & 1081.79 & 631.78 & 1400 & 1000 \\
\hline $\mathrm{TDS}(\mathrm{mg} / \mathrm{l})$ & Dry & 75.00 & 1879.00 & 545.96 & 285.72 & 500 & 500 \\
\hline $\mathrm{TH}(\mathrm{mg} / \mathrm{l})$ & Dry & 32.44 & 467.78 & 189.98 & 69.62 & 200 & 150 \\
\hline $\mathrm{SO}_{4}(\mathrm{mg} / \mathrm{l})$ & Dry & 11.55 & 225.57 & 78.16 & 40.68 & 250 & - \\
\hline $\mathrm{NO}_{3}(\mathrm{mg} / \mathrm{l})$ & Dry & 1.39 & 42.31 & 16.21 & 7.85 & 50 & - \\
\hline $\mathrm{HCO}_{3}(\mathrm{mg} / \mathrm{l})$ & Dry & 12.08 & 254.10 & 100.42 & 43.01 & 120 & - \\
\hline $\mathrm{Cl}(\mathrm{mg} / \mathrm{l})$ & Dry & 12.31 & 314.00 & 103.01 & 37.22 & 250 & 250 \\
\hline $\mathrm{Ca}(\mathrm{mg} / \mathrm{l})$ & Dry & 5.08 & 117.56 & 43.69 & 16.82 & 75 & - \\
\hline $\mathrm{Mg}(\mathrm{mg} / \mathrm{l})$ & Dry & 4.34 & 42.34 & 19.66 & 7.49 & 30 & 20 \\
\hline $\mathrm{Na}(\mathrm{mg} / \mathrm{l})$ & Dry & 5.15 & 154.00 & 52.28 & 21.46 & 200 & 200 \\
\hline $\mathrm{K}(\mathrm{mg} / \mathrm{l})$ & Dry & 0.75 & 20.54 & 6.86 & 2.81 & 10 & - \\
\hline $\mathrm{Fe}(\mathrm{ppm})$ & Dry & 0.01 & 5.52 & 0.77 & 1.09 & 0.3 & - \\
\hline
\end{tabular}

Table 2 Major cations and anions mean concentrations percentages (meq/l)

\begin{tabular}{l|lllll}
\hline & Cations & $\mathrm{Mg}^{2+}(\mathrm{meq} / \mathrm{l})$ & $\mathrm{Ca}^{2+}(\mathrm{meq} / \mathrm{l})$ & $\mathrm{Na}^{+}(\mathrm{meq} / \mathrm{l})$ & $\mathrm{K}^{+}(\mathrm{meq} / \mathrm{l})$ \\
\hline \multirow{3}{*}{$\%$ Mean } & Water samples & 16.05 & 35.67 & 42.68 & 5.60 \\
& & & & & \\
& Anions & $\mathrm{SO}_{4}{ }^{2-}(\mathrm{meq} / \mathrm{l})$ & $\mathrm{NO}_{3}{ }^{-}(\mathrm{meq} / \mathrm{l})$ & $\mathrm{HCO}_{3}{ }^{-}(\mathrm{meq} / \mathrm{l})$ & $\mathrm{Cl}^{-}(\mathrm{meq} / \mathrm{l})$ \\
\hline & Water samples & 26.25 & 16.21 & 33.72 & 34.59 \\
\hline
\end{tabular}


Table 3 Classification of water based on EC (US salinity Laboratory, 1954)

\begin{tabular}{|c|c|c|c|c|}
\hline Parameter & Range & Classification & Number of samples $(n=80)$ & $\begin{array}{l}\% \text { of } \\
\text { samples }\end{array}$ \\
\hline \multirow{4}{*}{$\begin{array}{l}\mathrm{EC} \\
(\mu \mathrm{S} / \mathrm{cm})\end{array}$} & $<250$ & Low & 7 (CP1, CP2, CP3, RV1, RV2, RV3 and RV4) & 9 \\
\hline & $\begin{array}{l}250- \\
750\end{array}$ & Medium & $\begin{array}{l}14 \text { (BH22, BH23, BH24, HDW13, HDW14, HDW15, } \\
\text { AM1, AM2, AM, AM4, AM5, AM6, AN8 and AM9) }\end{array}$ & 17 \\
\hline & $\begin{array}{l}750 \quad- \\
2250\end{array}$ & High & 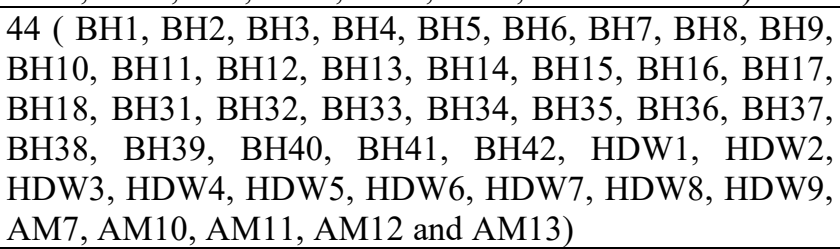 & 55 \\
\hline & $>2250$ & Very high & $\begin{array}{l}15(\mathrm{BH} 19, \mathrm{BH} 20, \mathrm{BH} 21, \mathrm{BH} 25, \mathrm{BH} 26, \mathrm{BH} 27, \mathrm{BH} 28, \\
\mathrm{BH} 29, \mathrm{BH} 30 \mathrm{BH} 43, \mathrm{BH} 44, \mathrm{BH} 45, \mathrm{HDW} 10, \mathrm{HDW} 11 \text { and } \\
\text { HDW12) }\end{array}$ & 19 \\
\hline
\end{tabular}

Table 4 Classification of water based on TDS (Davis \& DeWiest, 1966)

\begin{tabular}{|c|c|c|c|c|}
\hline Parameter & Range & Classification & Number of samples $(\mathrm{n}=80)$ & $\begin{array}{l}\% \text { of } \\
\text { samples }\end{array}$ \\
\hline \multirow[t]{4}{*}{$\begin{array}{l}\text { TDS } \\
(\mathrm{mg} / \mathrm{l})\end{array}$} & $<500$ & Desirable water & $\begin{array}{l}35 \text { (BH4, BH5, BH6, BH7, BH8, BH9, BH10, BH11, } \\
\text { BH12, BH22, BH23, BH24, HDW13, HDW14, HDW15, } \\
\text { AM1, AM2, AM3, AM4, AM5, AM6, AM7, AM8, } \\
\text { AM9, AM10, AM11, AM12, AM13, CP1, CP2, CP3, } \\
\text { RV1, RV2, RV3 and RV4) }\end{array}$ & 44 \\
\hline & $\begin{array}{l}500 \quad- \\
1000\end{array}$ & $\begin{array}{l}\text { Permissible } \\
\text { water }\end{array}$ & $\begin{array}{l}27 \text { (BH13, BH14, BH15, BH16, BH17, BH18, BH31, } \\
\text { BH32, BH33, BH34, BH35, BH36, BH37, BH38, BH39, } \\
\text { BH40, BH41, BH42, HDW1, HDW2, HDW3, HDW4, } \\
\text { HDW5, HDW6, HDW7, HDW8 and HDW9) }\end{array}$ & 34 \\
\hline & $\begin{array}{l}1000- \\
3000\end{array}$ & $\begin{array}{ll}\text { Useful } & \text { for } \\
\text { irrigation } & \end{array}$ & $\begin{array}{l}18(\mathrm{BH} 1, \mathrm{BH} 2, \mathrm{BH} 3, \mathrm{BH} 19, \mathrm{BH} 20, \mathrm{BH} 21, \mathrm{BH} 25, \mathrm{BH} 26, \\
\mathrm{BH} 27, \mathrm{BH} 28, \mathrm{BH} 29, \mathrm{BH} 30, \mathrm{BH} 43, \mathrm{BH} 44, \mathrm{BH} 45, \\
\text { HDW10, HDW11 and HDW12) }\end{array}$ & 22 \\
\hline & $>3000$ & $\begin{array}{lr}\text { Unfit } & \text { for } \\
\text { drinking } & \text { and } \\
\text { irrigation } & \\
\end{array}$ & Nil & Nil \\
\hline
\end{tabular}

Table 5 Classification of water based on TDS (Freeze \& Cherry, 1979)

\begin{tabular}{|c|c|c|c|c|}
\hline Parameter & Range & Classification & Number of samples $(n=80)$ & $\begin{array}{l}\% \text { of } \\
\text { samples }\end{array}$ \\
\hline \multirow[t]{4}{*}{$\begin{array}{l}\text { TDS } \\
(\mathrm{mg} / \mathrm{l})\end{array}$} & $<1,000$ & Fresh & 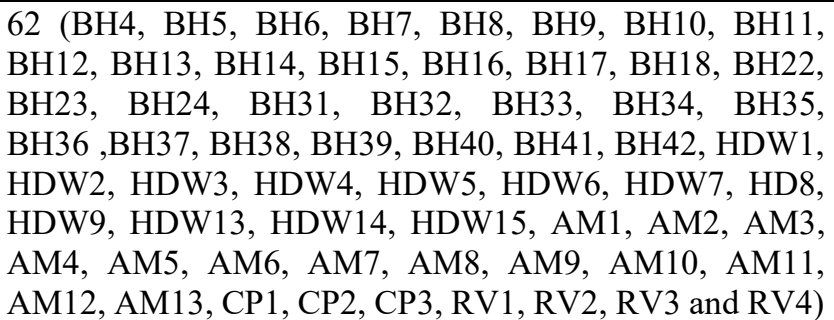 & 78 \\
\hline & $\begin{array}{l}1,000 \quad- \\
10,000\end{array}$ & Brackish & $\begin{array}{l}18 \text { (BH1, BH2, BH3, BH19, ВH20, BH21, ВH25, ВH26, } \\
\text { BH27, BH28, BH29, ВH30, BH43, BH44, BH45, HDW10, } \\
\text { HDW11, HDW12) }\end{array}$ & 22 \\
\hline & $\begin{array}{l}10,000- \\
100,000\end{array}$ & Saline & Nil & Nil \\
\hline & $\begin{array}{l}> \\
100,000\end{array}$ & Brine & Nil & Nil \\
\hline
\end{tabular}


Table 6 Classification of Water Based on Total Hardness (Sawyer \& McCarty, 1967)

\begin{tabular}{|c|c|c|c|c|}
\hline Parameter & Range & Classification & Number of samples $(n=80)$ & $\begin{array}{l}\% \text { of } \\
\text { samples }\end{array}$ \\
\hline \multirow{4}{*}{$\begin{array}{l}\mathrm{TH} \\
\mathrm{CaCO}_{3} \\
(\mathrm{mg} / \mathrm{l})\end{array}$} & $<75$ & Soft & 7 CP1, CP2, CP3, RV1, RV2, RV3, RV4) & 9 \\
\hline & $\begin{array}{ll}75- \\
150\end{array}$ & Moderate & $\begin{array}{l}8 \text { (BH22, BH23, HDW13, HDW14, HDW15, AM1, AM2 } \\
\text { and AM3) }\end{array}$ & 10 \\
\hline & $\begin{array}{l}150- \\
300\end{array}$ & Hard & 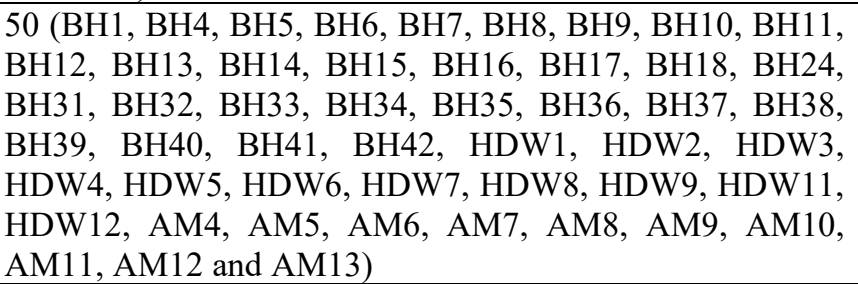 & 63 \\
\hline & $>300$ & Very Hard & $\begin{array}{l}15 \text { (ВH2, ВH3, ВH19, ВH20, ВH21, ВH25, ВH26, ВH27, } \\
\text { ВH28, ВH29, ВH30, ВH43, ВH44, BH45, HDW10) }\end{array}$ & 18 \\
\hline
\end{tabular}

\subsection{Hydrochemical facies}

Three hydrochemical facies types are revealed by the Piper diagram in the study area, namely, $\mathrm{Na}-\mathrm{Cl}$ facies, $\mathrm{Ca}-$ $\mathrm{HCO}_{3}$ facies and mixed Ca-Mg-Cl- $\mathrm{HCO}_{3}$ facies (Fig. 2).

Na-Cl facies (BH1, BH2, BH4, BH7, BH8, BH9, BH11, BH12, BH13, BH14, BH15, BH16, BH17, BH19, BH20, BH21, BH25, BH26, BH32, BH33, BH34, BH35, BH36, BH37, BH38, BH39, BH40, BH41, BH42, BH43, BH44, BH45, HDW1, HDW2, HDW3, HDW4, HDW5, HDW6, HDW7, HDW8, HDW9, HDW10 and HDW11). This hydrochemical facies indicates the dominance of alkali metals over alkaline earth metals $(\mathrm{Na}+\mathrm{K}>\mathrm{Ca}+\mathrm{Mg})$ and strong acidic anions over weak acidic anions $\left(\mathrm{Cl}+\mathrm{SO}_{4}>\mathrm{HCO}_{3}\right)$. The origin of $\mathrm{Na}-\mathrm{Cl}$ facies may be attributed to weathering of the lithographic units and dissolution of halite in water.

$\mathrm{Ca}_{-} \mathrm{HCO}_{3}$ facies (BH22, BH23, BH24, BH27, BH28, BH29, BH30, HDW12, AM13, AM8, AM9, AM10, AM11, AM12, CP1, CP2, CP3, RV1, RV2, RV3, and RV4 ) and this facies denotes the dominance of alkaline earth metal over alkali metals $(\mathrm{Ca}+\mathrm{Mg}>\mathrm{Na}+\mathrm{K})$ and weak anions over strong acidic anions $\left(\mathrm{HCO}_{3}>\mathrm{Cl}+\mathrm{SO}_{4}\right)$. This suggested that carbonate weathering domination and rock-water interaction are the primary factors in increasing the major ion concentration in water. The origin of $\mathrm{Ca}-\mathrm{HCO}_{3}$ facies could be traced to water recharge through precipitation. This facies type denotes primary (temporary) water hardness which relates to concentrations of calcium and magnesium in water and is usually expressed as an equivalent concentration of dissolved calcium carbonate $(\mathrm{CaCO} 3)$. Primary hardness in water causes scale in water heaters, boilers, pipes, and turbines; it also consumes excessive quantities of soap during washing activities. Primary hardness in water can be removed by boiling (Freeze \& Cherry 1979).

$\mathrm{Ca}-\mathrm{Mg}-\mathrm{Cl}-\mathrm{HCO}_{3}$ facies (BH3, BH6, BH10, BH5, BH18, BH22, BH31, HDW13, HDW14, HDW15, AM1, AM2, AM3, AM4, AM5, AM6 and AM7). This hydrochemical facies demonstrates the dominance of alkaline earth metals over the alkali metals $(\mathrm{Ca}+\mathrm{Mg}>\mathrm{Na}+\mathrm{K})$ and strong acidic anions over weak acidic anions $(\mathrm{Cl}+$ $\mathrm{SO}_{4}>\mathrm{HCO}_{3}$ ). This water type denotes the water originating from mixing process. The predominance of the Na$\mathrm{Cl}$ facies over the other two facies indicates a relatively short residence time of the groundwater in the fractured shale aquifer of the area.

The predominance of the halite water type over the other water types denotes that the groundwater is seawater in nature and the variation in chemistry may be as a result of rock-water interactions and anthropogenic activities. 


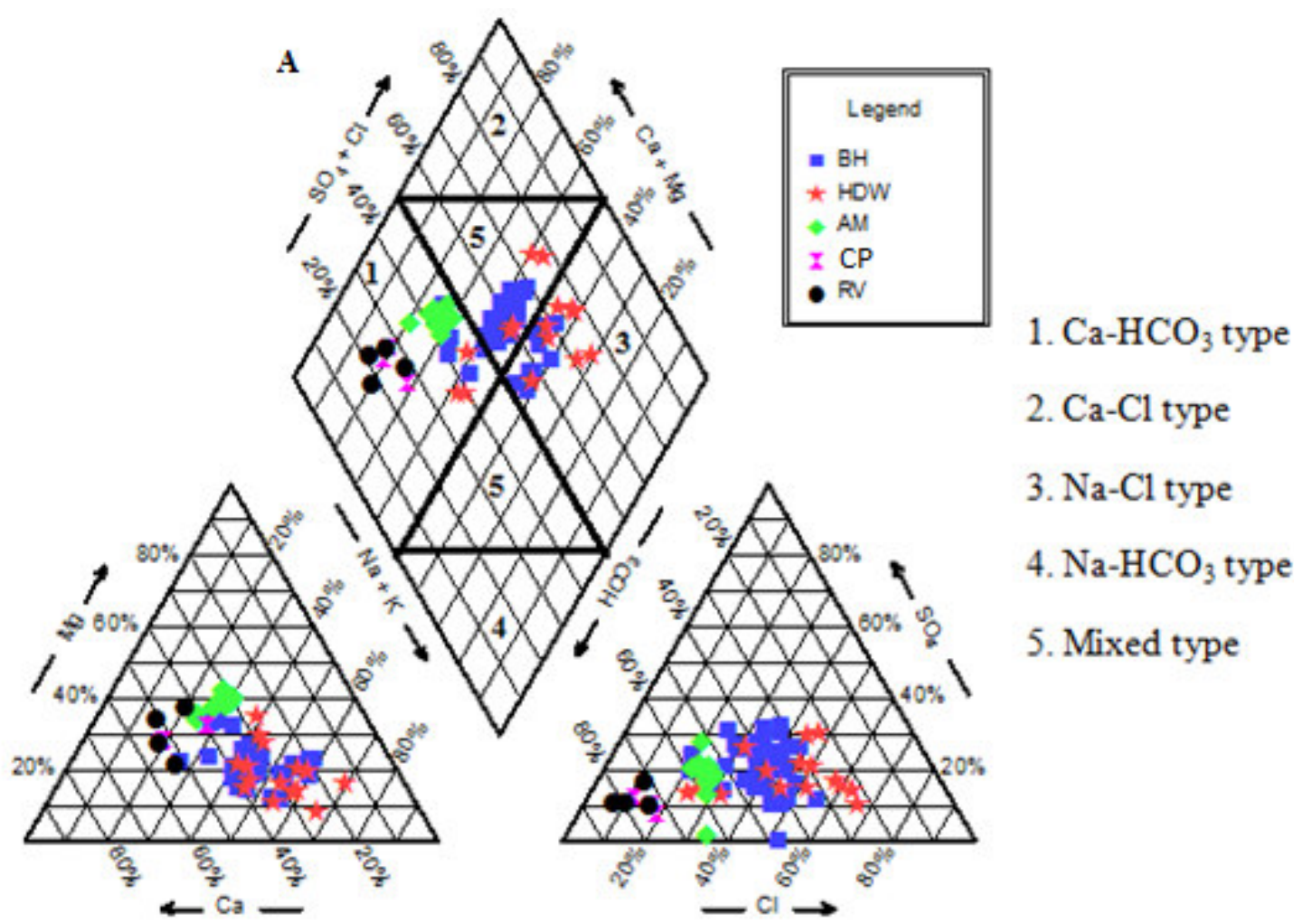

Figure 2 Piper diagram of the 80 water samples labeled according to the water sample type $(\mathrm{BH}=$ borehole, $\mathrm{HDW}=$ hand dug well, $\mathrm{AM}=$ abandoned mine, $\mathrm{CP}=$ catch pit, $\mathrm{RV}=$ river $)$

\subsection{Correlation Analysis}

Physiochemical parameters relationships

The degree of linear association between any two water quality parameters is measured by the correlation coefficient $(r)$ value. The correlation matrix of the physiochemical parameters in the study area is presented in Table 7. Parameters with correlation coefficient values that are significantly related at 0.01 and 0.05 levels are written with asterisks. The ionic pairs that are statistically related at 0.01 and 0.05 levels are thought to be released from the same sources or through same geochemical processes. The significant correlation between EC and the other hydrogeochemical parameters is highly positive with the exception of $\mathrm{K}^{+}, \mathrm{HCO}_{3}{ }^{-}, \mathrm{NO}_{3}{ }^{-}$, and $\mathrm{Fe}^{2+}$.

The $r$ value between EC and TDS is 0.983 , which means TDS is highly positively correlated with EC and can be predicted from $\mathrm{EC}$ with $98 \%$. Additionally, the $\mathrm{EC}$ value of the water samples has high positive correlation with TH, $\mathrm{Ca}^{2+}, \mathrm{Mg}^{2+}, \mathrm{Na}^{+}, \mathrm{Cl}^{-}$and $\mathrm{SO}_{4}{ }^{2-}$ with relative positive coefficient $r$ values of $0.828,0.804,0.830,0.889$, 0.824 and 0.858 respectively. These positive correlations between EC and some of the major ions indicate that an increase in these ions concentrations would increase the $\mathrm{EC}$ value of the water in the area. The strong correlation of the major elements $\mathrm{Ca}^{2+}, \mathrm{Mg}^{2+}, \mathrm{Na}^{+}, \mathrm{Cl}^{-}$and $\mathrm{SO}_{4}{ }^{2-}$ with EC is an indication of the contribution of these elements to the salinity or hardness of the water due to concentration of ions from evaporation of recharge water and water interaction with the geological formations. $\mathrm{pH}$ was found to be positively correlated $\left(0.05\right.$ level) to $\mathrm{K}^{+}$and $\mathrm{TH}$. This could be attributed to the anthropogenic influence on the water in the study area. The TDS values of the water samples show strong positive correlation with the major ions $\left(\mathrm{Ca}^{2+}, \mathrm{Mg}^{2+}, \mathrm{Na}^{+}, \mathrm{K}^{+}, \mathrm{HCO}_{3}^{-}, \mathrm{Cl}^{-}, \mathrm{SO}_{4}{ }^{2-}\right.$ and $\mathrm{NO}_{3}^{-}$, $)$ that constitute it in the water solution.

Table 4.17 also shows a strong positive correlation between $\mathrm{TH}$ and the cations $\mathrm{Ca}^{2+}$ and $\mathrm{Mg}^{2+}$. This relationship is in line with fact that TH is determined based on these two cations. $\mathrm{Ca}^{2+}$ shows highly positive correlation with $\mathrm{Mg}^{2+}$ compared to $\mathrm{Na}^{+}$and strong correlation with $\mathrm{Cl}^{-}$and $\mathrm{SO}_{4}{ }^{2-}$ compared to $\mathrm{HCO}_{3}{ }^{-}$. This could be an indication of the source of $\mathrm{Ca}^{2+}$ in the water (e.g. calcite, dolomite, gypsum and silicates) due to its strong association with $\mathrm{Mg}^{2+}$ and suggest the type of water found in the study area. $\mathrm{Mg}^{2+}$ positively correlated ( 0.01 level) to $\mathrm{Na}^{+}, \mathrm{HCO}_{3}{ }^{-}, \mathrm{Cl}^{-}$and $\mathrm{SO}_{4}{ }^{2-}$. $\mathrm{Na}^{+}$showed strong positive correlation with $\mathrm{Cl}^{-}$and $\mathrm{SO}_{4}{ }^{2-}$ besides TDS compared to $\mathrm{HCO}_{3}{ }^{-}$, which is an indication of the salinity found in some of the water samples. $\mathrm{Cl}^{-}$showed strong positive correlation with $\mathrm{SO}_{4}{ }^{2-}$ and $\mathrm{NO}_{3}{ }^{-}$. This could be an indication of surface contamination due to agricultural activities in the study area. 
Table 7 Pearson product moment correlations for water sampled

\begin{tabular}{|c|c|c|c|c|c|c|c|c|c|c|c|c|c|}
\hline & $\mathrm{pH}$ & $\mathrm{EC}$ & TDS & TH & $\mathrm{Ca}$ & $\mathrm{Mg}$ & $\mathrm{Na}$ & K & $\mathrm{HCO}_{3}$ & $\mathrm{Cl}$ & $\mathrm{SO}_{4}$ & $\mathrm{NO}_{3}$ & $\mathrm{Fe}$ \\
\hline $\mathrm{pH}$ & 1.000 & & & & & & & & & & & & \\
\hline $\mathrm{EC}$ & 0.162 & 1.000 & & & & & & & & & & & \\
\hline TDS & 0.145 & $0.983 * *$ & 1.000 & & & & & & & & & & \\
\hline $\mathrm{TH}$ & $0.259^{*}$ & $0.828^{* *}$ & $0.826^{* *}$ & 1.000 & & & & & & & & & \\
\hline $\mathrm{Ca}$ & 0.231 & $0.804 * *$ & $0.833^{* *}$ & $0.984 * *$ & 1.000 & & & & & & & & \\
\hline $\mathrm{Mg}$ & 0.127 & $0.830^{* *}$ & $0.784^{* *}$ & $0.788^{* *}$ & $0.719^{* *}$ & 1.000 & & & & & & & \\
\hline $\mathrm{Na}$ & 0.092 & $0.889 * *$ & $0.696^{* *}$ & 0.043 & $0.584 * *$ & $0.620 * *$ & 1.000 & & & & & & \\
\hline K & $0.273 *$ & 0.304 & $0.525^{* *}$ & 0.331 & $0.487^{* *}$ & 0.317 & $0.607^{* *}$ & 1.000 & & & & & \\
\hline $\mathrm{HCO}_{3}$ & 0.191 & 0.268 & $0.587^{* *}$ & 0.201 & $0.596^{* *}$ & $0.573 * *$ & $0.646^{* *}$ & $0.677^{* *}$ & 1.000 & & & & \\
\hline $\mathrm{Cl}$ & 0.221 & $0.824^{* *}$ & $0.831^{* *}$ & 0.344 & $0.851^{* *}$ & $0.603^{* *}$ & $0.835^{* *}$ & $0.810^{* *}$ & $0.668^{* *}$ & 1.000 & & & \\
\hline $\mathrm{SO}_{4}$ & 0.207 & $0.858^{* *}$ & $0.722 * *$ & 0.218 & $0.771^{* *}$ & $0.748 * *$ & $0.833^{* *}$ & $0.859^{* *}$ & $0.613 * *$ & $0.936^{* *}$ & 1.000 & & \\
\hline $\mathrm{NO}_{3}$ & 0.146 & 0.171 & $0.782^{* *}$ & 0.300 & 0.254 & 0.301 & 0.297 & 0.260 & $0.649 * *$ & $0.901^{* *}$ & $0.871^{* *}$ & 1.000 & \\
\hline $\mathrm{Fe}$ & 0.197 & 0.146 & 0.137 & 0.169 & 0.076 & 0.195 & -0.020 & $0.291^{*}$ & 0.173 & 0.158 & 0.173 & 0.059 & 1.000 \\
\hline
\end{tabular}

**Correlation is significant at the 0.01 level (2-tailed)

* Correlation is significant at the 0.05 level (2-tailed)

4.4 Sources of ions and their controlling processes

PCA was employed in the determination of the various sources of the ions and processes controlling water chemistry and it was performed on 13 variables (pH, EC, TDS, TH, $\mathrm{Ca}^{2+}, \mathrm{Mg}^{2+}, \mathrm{Na}^{+}, \mathrm{K}^{+}, \mathrm{Cl}^{-}, \mathrm{SO}_{4}{ }^{2-}, \mathrm{HCO}_{3}{ }^{-} \mathrm{NO}_{3}{ }^{-}$ and $\mathrm{Fe}^{2+}$ ) of the water samples in the study area. Table 8 shows the initial determined components, their Eigenvalues and the percent of variance contributed in each component. Only factors with Eigenvalues $\geq 1$ were taken into consideration and this resulted into two principle components (PCs) that were sufficient in explaining $78.544 \%$ of the variability in the original dataset from water samples. Absolute values of factor loadings of $\geq \pm 3.5$ were considered as strong correlation and rendered in bold and italic in Tables 8 to elucidate the relationship between the factors and the hydrochemical dataset. The two principle components shown in Table 8 are dominated by certain variables based on the prevailing hydrogeochemical processes and land use practices.

EC, TDS, TH, $\mathrm{Ca}^{2+}, \mathrm{Mg}^{2+}, \mathrm{Na}^{+}, \mathrm{SO}_{4}{ }^{2-}, \mathrm{Cl}^{-}$and $\mathrm{HCO}_{3}^{-}$have high positive loading factors on principal component (PC1) in water samples, explaining $15.521 \%$ of the variation in the total dataset (Table 8). PC 2 has high positive loadings on $\mathrm{pH}, \mathrm{K}^{+}$and $\mathrm{Fe}^{2+}$ and negative loading on $\mathrm{NO}_{3}{ }^{-}$, and $\mathrm{SO}_{4}{ }^{2-}$ in water samples which explained $78.544 \%$ of the variation in the total dataset (Table 8). As a result of the high associations and correlations between $\mathrm{Ca}^{2+}+\mathrm{Mg}^{2+}$ and $\mathrm{HCO}_{3}^{-}, \mathrm{Na}^{+}$, and $\mathrm{Cl}^{-}, \mathrm{PC} 1$ which explained the highest variance in the dataset may be defined as "hardness and salinity" factor. PC 2 which explained the least variance of the dataset has high negative loadings on $\mathrm{NO}_{3}{ }^{-}$and $\mathrm{SO}_{4}{ }^{2-}$. The occurrence of high loadings of $\mathrm{SO}_{4}{ }^{2-}$ in $\mathrm{PC} 1$ and $\mathrm{PC} 2$ suggest multiple sources for the ions. In $\mathrm{PC} 1, \mathrm{SO}_{4}{ }^{2-}$ has loading alongside with the major ions $\left(\mathrm{Ca}^{2+}, \mathrm{Mg}^{2+}, \mathrm{Na}^{+}, \mathrm{Cl}^{-}\right.$and $\left.\mathrm{HCO}_{3}{ }^{-}\right)$

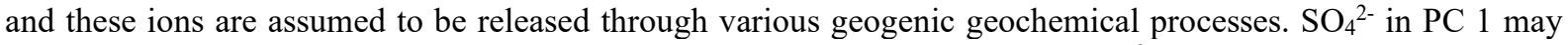
have been released from geogenic processes also. The geogenic source of $\mathrm{SO}_{4}{ }^{2-}$ may be derived from pyrite oxidation. The association of $\mathrm{NO}_{3}{ }^{-}$with $\mathrm{SO}_{4}{ }^{2-}$ in $\mathrm{PC} 2$ suggests anthropogenic source of $\mathrm{SO}_{4}{ }^{2-}$ in addition to its non-anthropogenic (geogenic) source. $\mathrm{NO}_{3}{ }^{-}$is usually derived from anthropogenic sources and the association of this ion with $\mathrm{SO}_{4}{ }^{2-}$ in $\mathrm{PC} 2$ suggests an anthropogenic source for $\mathrm{SO}_{4}{ }^{2-}$, in addition to those derived from oxidation of pyrite and related minerals. $\mathrm{NO}_{3}{ }^{-}$may be released from domestic wastes and agricultural activities; likewise $\mathrm{SO}_{4}{ }^{2-}$ may be released from domestic wastes as well as sulfate-rich fertilizers. PC 2 may be defined as "Anthropogenic" factor. 
Table 8 PC weights for water samples

\begin{tabular}{|l|ll|}
\hline \multicolumn{3}{|c|}{ water samples } \\
\hline Parameters & PC1 & PC2 \\
\hline $\mathrm{pH}$ & 0.027888 & $\mathbf{0 . 5 9 0 0 6 6}$ \\
$\mathrm{EC}$ & $\mathbf{0 . 3 7 1 8 4 9}$ & -0.090060 \\
$\mathrm{TDS}$ & $\mathbf{0 . 3 9 4 9 5 5}$ & -0.097633 \\
$\mathrm{TH}$ & $\mathbf{0 . 3 7 6 4 8 1}$ & -0.049898 \\
$\mathrm{SO}_{4}$ & $\mathbf{0 . 3 8 3 1 2 5}$ & $\mathbf{- 0 . 6 9 4 4 2 2}$ \\
$\mathrm{NO}_{3}$ & 0.282798 & $\mathbf{- 0 . 6 3 5 8 4 0}$ \\
$\mathrm{HCO}_{3}$ & $\mathbf{0 . 3 8 2 2 8 1}$ & 0.272429 \\
$\mathrm{Cl}$ & $\mathbf{0 . 3 6 3 4 0 1}$ & -0.138448 \\
$\mathrm{Mg}$ & $\mathbf{0 . 3 7 2 5 9 5}$ & 0.277652 \\
$\mathrm{Ca}$ & $\mathbf{0 . 3 9 5 5 2 4}$ & 0.039208 \\
$\mathrm{Na}$ & $\mathbf{0 . 3 8 8 5 3 4}$ & -0.127070 \\
$\mathrm{~K}$ & -0.059946 & $\mathbf{0 . 6 6 2 3 4 9}$ \\
$\mathrm{Fe}$ & 0.132577 & $\mathbf{0 . 6 8 9 3 6 0}$ \\
\hline Eigen value & 6.9335 & 1.70728 \\
\% variation & 63.032 & 15.521 \\
$\mathrm{Cumulative} \%$ variation & 63.032 & 78.544 \\
\hline
\end{tabular}

4.5 Pollution loading sources

Classification of water samples in the study area into water pollution loading classes was done using CA. The resulting dendrogram of the water in the area from water samples is presented in Figure 3. PCS generated from the PCA defined the pollution loading of the PCs on the water samples. This PCS was compared with the various cluster groups of the samples defined by the CA (Table 9) in order to differentiate samples with high pollution loading from those with low pollution loading. Water sampling stations with one or more of the PCS $\geq \pm 3.0$ were classified as high pollution loading, while $\mathrm{PCS}< \pm 3.0$ were classified as low pollution loading. Stations of the same groups have similar pattern of the water quality.

From Table 9, water samples in the study area can be grouped into eight, namely, CA1-1 group: from stations RV1, RV2, RV3, RV4, HDW13, HDW14 and HDW15; CA1-2 group: from stations CP1, CP2 and CP3; CA1-3 group: from stations BH22, BH23, BH24, AM1, AM2, AM3, AM4, AM5, AM6, AM7, AM8, AM9, AM10, AM11, AM12 and AM13; CA2-1: from stations HDW11 and HDW12; CA2-2 group: from stations BH10, BH11, BH38, BH39, BH12, BH37, BH40, BH41, BH42, BH34, BH35, ВH36, ВH31, BH32, ВH33, ВH13, ВH15, ВH14, ВH16, BH17, HDW4, HDW5, HDW6, HDW7 and HDW8; CA2-3 group: from station BH4, BH7, BH8, BH9, BH5, BH6, BH18, HDW1, HDW2, HDW3 and HDW9; CA3-1 group: from stations $\mathrm{BH} 25, \mathrm{BH} 26, \mathrm{BH} 27, \mathrm{BH} 28, \mathrm{BH} 29$, $\mathrm{BH} 30$ and HDW10; CA3-2 group: from station $\mathrm{BH} 1, \mathrm{BH} 2, \mathrm{BH} 3, \mathrm{BH} 19, \mathrm{BH} 20, \mathrm{BH} 21, \mathrm{BH} 43, \mathrm{BH} 44$ and $\mathrm{BH} 45$. CA1-1 group has a very high loadings $(>5.0)$ on $\mathrm{PC}$, indicating that that water sampled in those stations have high pollution resulting from weathering of the host minerals. CA1-2 group has low positive loadings (increasing impact) on PC1. CA1-3 group has high loadings $(<4.5)$ on PC1 but lower than CA1-1 group. Water samples from these stations resulted from weathering of the host minerals and anthropogenic activities. CA2-1 group has low negative loadings (decreasing impact) on PC1 and low positive loadings (increasing impact) on PC1. CA2-2 group has a very high loadings $(>5.0)$ on PC1 but higher than CA1-1 group, indicating that that water sampled in those stations have high pollution resulting from weathering of the host minerals. CA2-3 group has low positive loadings on PC1 and PC1. CA3-1 group has very high loadings on PC1. Water samples from these stations have high pollution resulting from weathering of the host minerals and mining activities. CA3-2 group has low positive loadings on PC1 and PC2. 
Distance

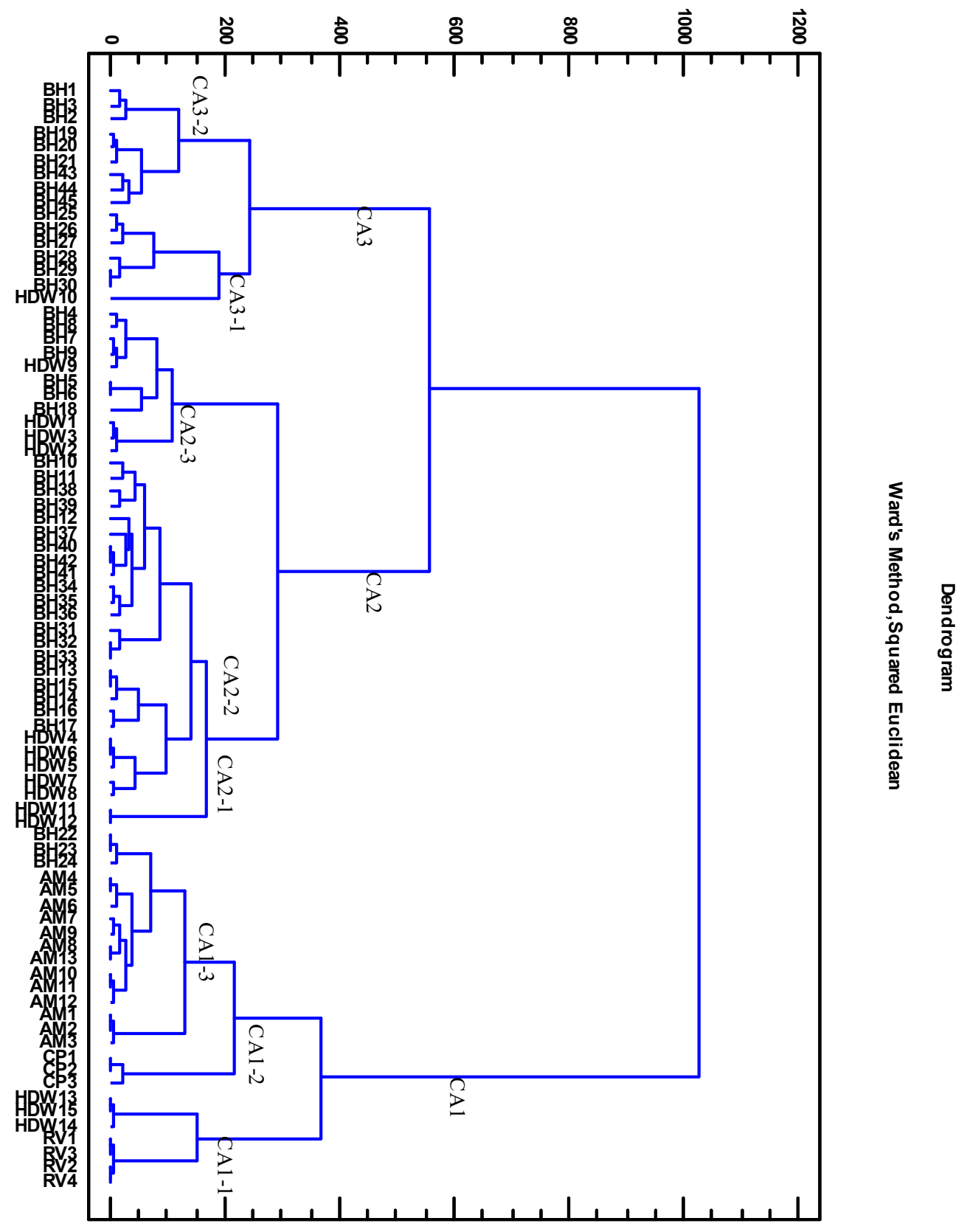

Figure 3 Dendrogram for water samples in the study area 
Table 9 Relationship between PCS determined by PCA and groups identified by CA of each sampling station for water samples in the study area

\begin{tabular}{|c|c|c|c|c|}
\hline S/No & Sampling station symbol & PC1 & PC2 & Group \\
\hline 1 & BH1 & 1.82927 & 0.90420 & CA3-2 \\
\hline 2 & $\mathrm{BH} 2$ & 2.56287 & 0.23274 & CA3-2 \\
\hline 3 & $\mathrm{BH} 3$ & 2.12868 & 0.49315 & CA3-2 \\
\hline 4 & $\mathrm{BH} 4$ & 1.82798 & 0.01110 & CA2-3 \\
\hline 5 & BH5 & 2.57282 & 0.57596 & CA2-3 \\
\hline 6 & BH6 & 2.13704 & 0.18887 & CA2-3 \\
\hline 7 & $\mathrm{BH} 7$ & 2.63118 & 0.72879 & CA2-3 \\
\hline 8 & $\mathrm{BH} 8$ & 2.17246 & 0.57813 & CA2-3 \\
\hline 9 & BH9 & 2.22849 & 0.24394 & CA2-3 \\
\hline 10 & BH10 & -2.04340 & 1.56996 & CA2-2 \\
\hline 11 & BH11 & -2.59071 & 1.44082 & CA2-2 \\
\hline 12 & BH12 & -1.80706 & 1.53335 & CA2-2 \\
\hline 13 & BH13 & -2.04662 & 0.09641 & CA2-2 \\
\hline 14 & BH14 & \begin{tabular}{|l}
-2.16085 \\
\end{tabular} & 0.85764 & CA2-2 \\
\hline 15 & BH15 & -0.37821 & 0.74614 & CA2-2 \\
\hline 16 & BH16 & 0.51725 & -1.58743 & CA2-2 \\
\hline 17 & BH17 & 0.89687 & -1.51547 & CA2-2 \\
\hline 18 & BH18 & 0.59606 & -0.69726 & CA2-3 \\
\hline 19 & BH19 & 0.43324 & 2.23031 & CA3-2 \\
\hline 20 & $\mathrm{BH} 20$ & 0.55802 & 1.66979 & CA3-2 \\
\hline 21 & BH21 & 2.85325 & 0.19534 & CA3-2 \\
\hline 22 & $\mathrm{BH} 22$ & 3.41873 & 0.57245 & CA1-3 \\
\hline 23 & $\mathrm{BH} 23$ & 2.89338 & 0.16607 & CA1-3 \\
\hline 24 & BH24 & 2.45025 & 0.32344 & CA1-3 \\
\hline 25 & BH25 & -4.95874 & 0.72952 & CA3-1 \\
\hline 26 & BH26 & -5.35574 & 0.66757 & CA3-1 \\
\hline 27 & BH27 & -4.49624 & 0.97004 & CA3-1 \\
\hline 28 & BH28 & -5.11779 & 0.87049 & CA3-1 \\
\hline 29 & BH29 & -4.72056 & 1.08475 & CA3-1 \\
\hline 30 & BH30 & -4.90861 & 0.92342 & CA3-1 \\
\hline 31 & BH31 & 6.09478 & 1.72565 & CA2-2 \\
\hline 32 & BH32 & 5.22575 & 1.73904 & CA2-2 \\
\hline 33 & BH33 & 5.27227 & 0.91681 & CA2-2 \\
\hline 34 & BH34 & -0.60531 & 1.79205 & CA2-2 \\
\hline 35 & BH35 & -0.44386 & 1.36674 & CA2-2 \\
\hline 36 & BH36 & -0.40420 & 1.17315 & CA2-2 \\
\hline 37 & BH37 & 1.02026 & 1.08929 & CA2-2 \\
\hline 38 & BH38 & 0.48748 & 0.721645 & CA2-2 \\
\hline 39 & BH39 & 0.85002 & 4.12451 & CA2-2 \\
\hline 40 & BH40 & -0.00881 & 0.861002 & CA2-2 \\
\hline 41 & BH41 & -0.72494 & 0.532729 & CA2-2 \\
\hline 42 & BH42 & -1.05545 & 0.345432 & CA2-2 \\
\hline 43 & BH43 & 0.00936 & 0.537573 & CA3-2 \\
\hline 44 & BH44 & 0.16595 & 0.32242 & CA3-2 \\
\hline 45 & BH45 & 0.17610 & 0.437446 & CA3-2 \\
\hline 46 & HDW1 & 2.50717 & 0.142913 & CA2-3 \\
\hline 47 & HDW2 & 1.79351 & 0.344045 & CA2-3 \\
\hline 48 & HDW3 & 2.54799 & 0.047006 & CA2-3 \\
\hline 49 & HDW4 & -0.10508 & 0.112235 & CA2-2 \\
\hline 50 & HDW5 & -0.33643 & 0.30146 & CA2-2 \\
\hline 51 & HDW6 & -0.36697 & 0.06452 & CA2-2 \\
\hline 52 & HDW7 & -0.59834 & 0.99227 & CA2-2 \\
\hline
\end{tabular}




\begin{tabular}{|c|c|c|c|c|}
\hline 53 & HDW8 & -0.99293 & 0.90948 & CA2-2 \\
\hline 54 & \begin{tabular}{|l|} 
HDW9 \\
\end{tabular} & 1.39000 & 0.37997 & CA2-3 \\
\hline 55 & HDW10 & -8.21952 & -4.14732 & CA3-1 \\
\hline 56 & HDW11 & -0.89655 & 0.21615 & CA2-1 \\
\hline 57 & HDW12 & -1.03786 & 0.89520 & CA2-1 \\
\hline 58 & HDW13 & -5.57605 & 0.82666 & CA1-1 \\
\hline 59 & HDW14 & -5.93389 & 0.65090 & CA1-1 \\
\hline 60 & HDW15 & -5.93020 & 0.07382 & CA1-1 \\
\hline 61 & AM1 & 0.19396 & -0.71332 & CA1-3 \\
\hline 62 & AM2 & 0.59446 & -0.17569 & CA1-3 \\
\hline 63 & AM3 & 0.29066 & -0.97082 & CA1-3 \\
\hline 64 & AM4 & 2.97160 & -0.52053 & CA1-3 \\
\hline 65 & AM5 & -2.86194 & -0.36074 & CA1-3 \\
\hline 66 & AM6 & \begin{tabular}{|l|}
-3.19693 \\
\end{tabular} & -0.04573 & CA1-3 \\
\hline 67 & AM7 & -3.09291 & -0.03843 & CA1-3 \\
\hline 68 & AM8 & -2.66822 & -0.20159 & CA1-3 \\
\hline 69 & AM9 & -2.07986 & -2.31960 & CA1-3 \\
\hline 70 & AM10 & 4.70568 & 1.08337 & CA1-3 \\
\hline 71 & AM11 & 4.97288 & 1.91069 & CA1-3 \\
\hline 72 & AM12 & 3.81712 & 1.86501 & CA1-3 \\
\hline 73 & AM13 & 3.86075 & 0.04258 & CA1-3 \\
\hline 74 & CP1 & 2.62018 & -1.25641 & CA1-2 \\
\hline 75 & $\mathrm{CP} 2$ & 2.97707 & -0.66192 & CA1-2 \\
\hline 76 & $\mathrm{CP} 3$ & 2.12481 & \begin{tabular}{|l|}
-0.41966 \\
\end{tabular} & CA1-2 \\
\hline 77 & RV1 & 2.83963 & -1.31266 & CA1-1 \\
\hline 78 & RV2 & 2.87659 & -0.43216 & CA1-1 \\
\hline 79 & RV3 & 2.28991 & \begin{tabular}{|l|}
-2.81466 \\
\end{tabular} & CA1-1 \\
\hline 80 & RV4 & -0.09206 & -0.55648 & CA1-1 \\
\hline
\end{tabular}

\subsection{Discriminating physiochemical factors}

DA was used to find out one or two functions (linear combinations) of observed data (discriminating functions) that best separate the water quality (high pollution loading and low pollution loading) of each of the water sampled in the area. One discriminating function (DF) which has the following qualities: eigenvalue $>1.0$, relative percentage explained $>70 \%$, and high canonical correlation $>0.5$ (Mahmood et al. 2001) was extracted in the samples and was found to efficiently discriminate the water quality (Table 10). Wilk's lambda test showed that the extracted DF is a statistically significant DF because the $P$ value is $<0.05$ confidence (Table 4.9). The DF coefficient for water samples is presented in Table 11. From Table 11, EC, TDS, TH, $\mathrm{SO}_{4}, \mathrm{Cl}, \mathrm{Mg}, \mathrm{Ca}, \mathrm{Na}$, and $\mathrm{HCO}_{3}$ was found to best discriminate the water quality in the area. The DA shows that ions of both geogenic $(\mathrm{Ca}$, $\mathrm{Mg}, \mathrm{SO}_{4}$ and $\left.\mathrm{HCO}_{3}\right)$ and anthropogenic $(\mathrm{Cl})$ origins best discriminate the water quality in the study area.

Table 10 Eigenvalue and Wilk's lambda test of DFs for spatial variation of water quality in the study area.

\begin{tabular}{|l|l|l|l|l|l|l|l|}
\hline & Eigenvalue & $\begin{array}{l}\text { Relative } \\
\text { Percentage }\end{array}$ & $\begin{array}{l}\text { Canonical } \\
\text { Correlation }\end{array}$ & $\begin{array}{l}\text { Wilks } \\
\text { Lambda }\end{array}$ & $\begin{array}{l}\text { Chi- } \\
\text { Square }\end{array}$ & DF & P-Value \\
\hline Water samples & 2.74592 & 100.00 & 0.85618 & 0.266957 & 64.0524 & 18 & 0.0000 \\
\hline
\end{tabular}


Table $11 \mathrm{DF}$ coefficients of the spatial variation of water quality in the study area

\begin{tabular}{|l|l|}
\hline Parameters & Water samples (DF coefficient) \\
\hline $\mathrm{pH}$ & 0.218 \\
\hline $\mathrm{EC}$ & -283.682 \\
\hline $\mathrm{TDS}$ & -154.784 \\
\hline $\mathrm{TH}$ & 537.807 \\
\hline $\mathrm{SO}_{4}$ & -183.547 \\
\hline $\mathrm{NO}_{3}$ & 51.384 \\
\hline $\mathrm{HCO}$ & -152.727 \\
\hline $\mathrm{Cl}$ & -221.118 \\
\hline $\mathrm{Mg}$ & 142.876 \\
\hline $\mathrm{Ca}$ & 145.983 \\
\hline $\mathrm{Na}$ & 142.860 \\
\hline $\mathrm{K}$ & -62.382 \\
\hline $\mathrm{Fe}$ & 1.092 \\
\hline
\end{tabular}

\section{Conclusion}

The study showed that the analysis of hydrochemical data using the multivariate statistical techniques such as (PCA, CA and DA) can give some information not available at first glance in the conventional hydrogeochemical analyses techniques. The classification of water types and dominant ions based on Piper diagram is: $\mathrm{Na}^{+}-\mathrm{Cl}^{-}$type, $\mathrm{Ca}^{2+}-\mathrm{HCO}_{3}{ }^{-}$type and $\mathrm{Ca}^{2+}-\mathrm{Mg}^{2+}-\mathrm{Cl}^{-}-\mathrm{HCO}_{3}{ }^{-}$type, with $\mathrm{Na}^{+}-\mathrm{Cl}^{-}$as the dominant water type. For all samples, the order of abundance in ions is $\mathrm{Cl}^{-}>\mathrm{HCO}_{3}{ }^{-}>\mathrm{SO}_{4}{ }^{2-}>\mathrm{NO}_{3}{ }^{-}$, for anions and $\mathrm{Na}^{+}>\mathrm{Ca}^{2+}>\mathrm{Mg}^{2-}>\mathrm{K}^{+}$, for cations.

PCA converted the thirteen parameters into two principle components (PCs), which explained $78.553 \%$, of the total variance. The first principle component (PC1) termed as "hardness and salinity" factor, explained $63.032 \%$ of the total variance. The second principle component (PC2) can be termed as "anthropogenic" factor, which explained $15.521 \%$ of the total variance. CA grouped 80 water samples in the area into eight clusters of similar water quality characteristics related to water-rock interaction, agriculture and anthropogenic sources. DA has shown that the principal physiochemical parameters which distinguish the water quality in the area are of geogenic and anthropogenic origins.

Hence, this study illustrates that multivariate statistical analysis is an excellent empirical tool for understanding complex water quality data sets and for understanding spatial variations, which are useful and effective for water quality management.

\section{References}

Amajor, L.C. (1992), Storm Induced Turbidity-like Deposits: An example from the Turonian Eze-Aku Formation at Nkalagu, South eastern Nigeria, Nigeria Jour of Min and Geol., 28(1), 7-17.

APHA (2005), Standard methods for the examination of water and wastewater, 20th edn. American Public Health Association, Washington, DC.

Ayuba, R., Omonona, O.V. \& Onwuka, O.S. (2013), Assessment of groundwater quality of Lokoja Basement area, Journal of Geological Society of India, 82, 413-420.

Datta, D. \& Subramanian, V. (1998), Distribution and fractionation of heavy metals in the surface sediments of the Ganges-Brahmaputra-Meghna river system in the Bengal basin, Environmental Geology, 36, 93-101. https://doi.org/10.1007/s002540050324.

Davis, S.N. \& DeWiest, R.J. (1966), Hydrogeology, New York: Wiley.

Eyankware, M.O., Nnajieze, V.S. \& Aleke, C.G. (2018), Geochemical Assessment of Water Quality for Irrigation Purpose, in Abandoned Limestone Quarry pit at Nkalagu area, Southern Benue Trough Nigeria, Environmental Earth Sci. Jour., 30(10), 245-260.

Ezekwe, I.C., Odubo, E., Chima, G.N. \& Onwuchekwa, I.S. (2012), Groundwater occurrence and flow patterns in the Ishiagu mining area of southeastern Nigeria, Frontiers of Earth Science, 6(1), 18-8.

Fayose, E.A. \& De Klasz, I. (1976), Microfossils of the Eze Aku Formation (Turonian) at Nkalagu quarry Eastern Nigeria, Nigeria Journal. M. Geol. 13, 51-61.

Freeze, A. \& Cheery, J.A. (1979), Groundwater, Prentice-Hall Inc., Eagle Wood Cliffs, New Jersey, 491.

Güler, C., Thyne, G.D., McCray, J. E. \& Turner, A.K. (2002), Evaluation of graphical and multivariate statistical methods for classification of water chemistry data, Hydrogeology

Haran, A.V.L.N.S.H.H. (2002), Evaluation of drinking water quality at jalaripeta village of visakhapatnam district, andhra pradesh, Nature, Environment and Pollution Technology, 1(4), 407-410.

Harman, H. H. (Ed.). (1967), Modern factor analysis (2nd ed.), Chicago, Ill.: University of Chicago Press Inyang, P.B.E. (1975), Climate, In O. Gek (Ed.), Nigeria in maps, Eastern State, Benin City: Ethiope Pub. House, 
25-26. Journal, 10, 455-474.

Kaiser, H.F. (1958), The varimax criterion for analytic rotation in factor analysis, Psychometrika, 23, 187-200.

Lu, K.L., Liu, C.W. \& Jang, C.S. (2011), Using multivariate statistical methods to assess the groundwater quality in an arsenic-contaminated area of southwestern Taiwan, Environmental Monitoring and Assessment, 184(10), 6071-85, DOI: 10.1007/s10661-011-2406-y.

Mahmood, A., Muqbool, W., Mumtaz, M.W. \& Ahmad, F. (2011), Application of multivariate statistical techniques for the characterization of groundwater quality of Lahore, Gujranwala and Sialkot (Pakistan), Pakistan Journal of Analytical and Environmental Chemistry, 12(1\& 2), 102-112.

Mohapatra, P.K., Vijay, R., Pujari, P.R., Sundaray, S.K. \& Mohanty, B.P. (2011), Determination of processes affecting groundwater quality in the coastal aquifer beneath Puri city,India: a multivariate statistical approach, Water Science and Technology, 64(4), 809-817.

Okogbue, C.O., Omonona, O.V. \& Aghamelu, O.P. (2012), Qualitative assessment of groundwater from EgbeMopa basement complex area, Northcentral Nigeria, Environmental Earth Science, 67, 1069-1083.

Omonona, O.V. \& Okogbue, C.O. (2017), Geochemistry of rare earth elements in groundwater from different aquifers in the Gboko area, central Benue Trough, Nigeria, Environmental Earth Sciences. https://doi.org/10.1007/s12665-016-6329-3

Omonona, O.V., Amah, J.O., Olorunju, S.B. et al. (2019), Hydrochemical characteristics and quality assessment of groundwater from fractured Albian carbonaceous shale aquifers around Enyigba-Ameri, southeastern Nigeria, Environmental Monitoring and Assessment, 191(125), 1-22, https://doi.org/10.1007/s10661-019-7236-3

Omonona, O.V., Onwuka, O.S. \& Okogbue, C.O. (2014), Characterization of groundwater quality in three of Enugu settlement areas metropolis, southeastern Nigeria, using multivariate analysis, Environmental Monitoring and Assessment, 186(2), 651-664.

Onwuka, O.S., Uma, K.O. \& Ezeigbo, H.I. (2004), Potability of shallow groundwater in Enugu Town, Southeastern Nigeria, Global Journal of Environmental Sciences, 3(1 \& 2), 33-39.

Ribeiro, L. \& Macedo, M.E. (1995), Application of multivariate statistics, trend and cluster analysis to groundwater quality in the Tejo and Sado aquifer. Groundwater quality: Remediation and protection, Proceedings of an International Conference, Prague, Czech Republic, 15-18 May, 39-47.

Samson S. \& Elangovan, K. (2017), Multivariate statistical analysis to assess groundwater quality in Namakkal district, Tamil Nadu, India, Indian Journal of Geo-Marine Sciences, 46(4):830-836

Sawyer, C.N. \& McCarty, P.L. (1967), Chemistry for sanitary engineers (2nd edn.), New York: Education, McGraw-Hill.

Senthilkumar, G., Ramanathan, A.L., Nainwal, H.C. \& Chidambaram, S. (2008), Evaluation of the hydrogeochemstry of groundwater using factor analysis in the Cuddalore coastal region, Tamil Nadu, India, Indian Journal of Marine Science, 37(2), 181-185.

Shihab, A.S. \& AbdulBaqi, Y.T. (2010), Multivariate analysis of groundwater quality of Makhmor Plain North Iraq, Damascus University Journal, 26(1), 19-26.

Singh, A.K. \& Hassin, S.I. (2002), Aspects of weathering and solute acquisition processes controlling chemistry of sub-Alpine proglacial streams of Garhwal Himalaya, India, Hydrological Processes, 16, 835-849.

Singh, K.P., Malik, A., Mohan, D. \& Sinha, S. (2004), Multivariate statistical techniques for the evaluation of spatial and temporal variations in water quality of Gomti River (India) - A case study, Water Research, 38, 3980-3992.

Singh, S.K., Singh, C.K., Kumar, K.S., Gupta, R. \& Mukherjee, S. (2009), Spatial-temporal monitoring of groundwater using multivariate statistical techniques in Bareilly District of Uttar Pradesh, India, Journal of Hydrology and Hydromechanics, 57(1), 45-54.

SON, (2007). Nigerian industrial standard: Nigeria standard for drinking water quality. Standard Organization of Nigeria, 1687 Lome street Wuse, Abuja ICS 13.060.20.

US Salinity Laboratory Staff (1954). Diagnosis and improvement of saline and alkali soils, USDA, Handbook 60, U.S. Government Printing Office, Washington D. C.

Ward, J.H. (1963), Hierarchical grouping to optimize an objective function, Journal of the American Statistical Association, 58(301), 236-244.

World Health Organization (WHO), (2011), Guidelines for drinking water quality criteria. $4^{\text {th }}$ ed. Geneva, 307 441 